\title{
Public Pensions and Labor Force Participation: The Case of Greece
}

\author{
Milton Nektarios \\ University of Piraeus, 80, Karaoli \& Dimitriou St., 18534 Piraeus, Greece. \\ E-mail: nektar2@otenet.gr
}

The pension system of Greece is a representative case of the "Mediterranean welfare state", which is characterized by extensive segmentation, very high payroll tax rates, and yet inadequate pension benefits. In order to explain this paradox we construct an economic-demographic model. We show that in the period 1980-2000, the segmentation of the system and the very low labor force participation rates of the Greek economy have resulted in very high payroll tax rates in relation to the current level of benefits. On top of these problems, the expected adverse demographic developments in the period 2005-2050 will render the pension system completely unsustainable. Major reform proposals are suggested to remedy this situation, which threatens the public finances of the country.

The Geneva Papers (2007) 32, 553-569. doi:10.1057/palgrave.gpp.2510144

Keywords: demographic changes; pension system in Greece; economic unsustainability; need for reform

\section{Introduction}

On top of the demographic problem, public pension systems in some countries have to face the consequences of low labor force participation rates. This phenomenon proceeds from the demographic developments and exacerbates the adverse financial effects of the latter. With widespread pension rights for the retired population, many public pension systems suffer severe financial problems currently because of very low labor force participation rates, which worsen substantially the "economic dependency ratios" (retired/employed labor force), even though the demographic factors have not affected yet the "dependency ratios" (retired/active population).

Greece has a public pension system that operates on a pay-as-you-go (PAYG) basis, and its finances have suffered during the post-war period from relatively low labor force participation rates. Greece still has the lowest labor force participation rates in the EU-15. The problem is exacerbated by the extreme segmentation of the pension system and the concomitant extensive contribution evasion. All these have led to the creation of substantial deficits in the pension system since the late 1980s. Still worse, the country has not undertaken so far any serious initiatives to reform the pension system in view of the adverse demographic problems that will prevail in the coming decades. 
The Geneva Papers on Risk and Insurance - Issues and Practice

554

Table 1 Main pension funds in Greece, 1998

\begin{tabular}{lcc}
\hline Employment group & $\begin{array}{c}\text { Number of insured } \\
\text { (thousands) }\end{array}$ & $\begin{array}{c}\text { Number of pensioner } \\
\text { (thousands) }\end{array}$ \\
\hline Private sector wage earners & 1.900 & 872 \\
Farmers & 1.135 & 759 \\
Non-agricultural self-employed & 897 & 239 \\
Civil servants & 423 & 350 \\
Employees in public corporations & 81 & 57 \\
\hline
\end{tabular}

Source: Government of Greece (2001a, b).

Greece is a representative case of the "Mediterranean welfare state". ${ }^{1}$ The basic characteristics of its pension system are: (a) extensive segmentation, (b) high payroll tax rates, and (c) inadequate benefits. In this paper, we shall undertake the quantification of the Mediterranean welfare model in order to resolve the paradox of high payroll tax rates and the coexistence of low pension benefits. We construct an economic-demographic model in order to capture the influence of the economy on the pension system by incorporating variables for productivity, unemployment, mortality, and birth rates. We introduce explicit variables for the labor force participation rate and the retirement age. We use this model to simulate the period 1980-2000, in order to estimate the effects of the economic variables on the actual cost of the pension system. Then, we use the model to make cost projections for the period 2005-2050.

The following section includes a brief description of the Greek pension system. In the next section, we develop the economic-demographic model. In the following section, we undertake a simulation of pension costs for the period 1980-2000, as well as a sensitivity analysis. In the next section, we make projections for the costs of the current pension system up to 2050. Options for reform that result from the previous analysis are developed in the penultimate section, and the final section provides the conclusions.

\section{The public pensions system}

The public pension system in Greece is highly segmented and complex, containing 24 primary pension funds and more than 120 supplementary funds, with many different regulations for pension rights. The primary pension funds can be classified by employment category into five groups (Table 1). The supplementary funds cover much smaller groups of workers than primary funds and are often based on enterprise agreements.

Data in Table 1 are based on the most recent comprehensive actuarial study that was carried out around 2000 on the basis of 1998 data. $^{2}$

The standard contribution rates for primary pensions are 6.67 percent for the employee, 13.33 percent for the employer, and 10 percent by the Government.

\footnotetext{
${ }^{1}$ Ferrera (1996).

${ }^{2}$ Government of Greece (2001a, b).
} 
For supplementary pensions, the standard rates are 3 percent for the employee and 3 percent for the employer. It is important to note that the supplementary funds are not funded, and they effectively operate as PAYG schemes.

In spite of these relatively high contribution rates, the contribution income from employers and employees is insufficient to cover the current level of pensions. The state in effect finances the deficits through the budget process.

The complexity and segmentation of the pension system obscures the factors which are straining its finances. Not surprisingly, the common theme to all groups of funds is the generosity of individual payments relative to contributions. Nevertheless, pensioners complain about low primary pensions. This paradox is partially resolved by the fact that contributions have been quite low in the past and often for short periods. In addition, pensions start at an early age - usually before the age of 55 in the public sector and near the age of 60 in the private sector. Farmers' pensions are essentially a flat welfare benefit, which is less than 30 percent of the minimum pension for wage earners (a primary fund for farmers was established in 1998). For these reasons, the actual replacement rate for the overall pension system in Greece is low (see below), despite the fact that the nominal replacements rates are quite generous ( 70 percent for primary pensions and about 20 percent for supplementary pensions).

Moreover, the complexity and segmentation of the public pension system, in conjunction with poor administration, has led to a lack of transparency and inadequate monitoring. As a result, pension fraud is difficult to detect and contribution evasion is sizeable and is estimated in the range of 20-30 percent of current revenues. ${ }^{3}$ Many studies have demonstrated the lack of an adequate organization of the system and the inequity of insurance conditions and pension rights involved in the resulting intragenerational and intergenerational transfers. ${ }^{4}$

The pension funds offer defined benefits based on employer-employee contributions, and they generally operate as PAYG schemes. As for any other PAYG system, the future finances of the Greek pension system depend critically on:

- demographic changes, and especially the trend in the number of workers relative to the number of pensioners;

- the changes in the average amount of pensions relative to average earnings; and

- the length of working life and retirement period.

Major studies of the Greek pension system ${ }^{5}$ have pointed to loose eligibility conditions combined with perverse incentives, which foster early retirement and contribution evasion, as the main shortcomings of the current public pension system. Those country-specific problems are on top of the demographic problem, which is quite intensive for Greece. As a result, the long-term projections indicated that the unfunded liabilities of the PAYG system are among the highest in OECD countries.

\footnotetext{
${ }^{3}$ Tatsos (2001).

${ }^{4}$ Center for Economic Planning and Research (1976); Ministry of Social Services (1981); Provopoulos (1987); Nektarios (1996); OECD (1997); Commission for the Long-run Economic Policy (1997).

5 OECD (1997); Mylonas and de la Maisonneuve (1999).
} 
556

The present value of future pension liabilities, net only of employer and employee contributions, was estimated to be of the order of 200 percent of GDP. ${ }^{6}$

Most diagnostic studies have failed to distinguish between the symptoms and the causes of the problem, in the past and in the future. It is true that in the future, the inherent "generosity" of the system along with the evolving demographic factors will result in the largest increase in pension costs of any EU-15 country. ${ }^{7}$ However, in the past, the essence of the problem was not so much the generosity of the system as the inadequacy of the revenue side, despite the fact of the very high contribution rates in the period 1980-2000. In fact, the average annual pension in 2004 was $€ 6,380$, whereas about 65 percent of pensioners received minimum pensions. ${ }^{8}$ We shall show in this paper that the real causes of this paradox of low pensions and high contribution rates have been: (a) the extreme segmentation of the system and (b) the very low labor force participation rate. In order to do that, we undertake the construction of the appropriate model in the next section.

\section{An economic-demographic model of the PAYG system}

The essence of a PAYG pension system is a tax-transfer mechanism that redistributes income from the active to the retired population. Our mathematical model focuses on the influence of the economic-demographic environment on the PAYG system.

The basic economic units in our model are the "average worker" and the "average pensioner". The former earns the average wage for each year of his/her working life, and the latter receives the average pension for each year of his/her retirement life. The length of working life is $n$ years and people retire at the age of 65 . Retired people die at the rate $\delta$ per annum; deaths are concentrated at the beginning of the year. Babies are born at the rate $d$ per annum. The complete demographic model is developed in the Appendix.

At any year $t$ the total labor force $L_{t}$ is given by the expression:

$$
L_{t}=L_{0} d \frac{1}{n} \mathrm{e}^{n(t-64)}\left(\mathrm{e}^{n n-1}\right)
$$

where $L_{0}$ is the labor force at time zero, and $n$ is the growth rate of the labor force annually.

At any year $t$ the retired population $R_{t}$ is given by the expression:

$$
R_{t}=L_{0} d \frac{1}{\delta+n} \mathrm{e}^{-\delta} \mathrm{e}^{n(t-65)}
$$

The PAYG system covers a certain portion of the labor force each year. We denote this coverage by $\beta_{t}$, and it may change from year to year as coverage expands. Also, the unemployment rate is $u_{t}$.

\footnotetext{
${ }^{6}$ Mylonas and de la Maisonneuve (1999); Roseveare et al. (1996).

${ }^{7}$ IMF (2006).

${ }^{8}$ Ibid.
} 
Average earnings grow at the rate $\lambda$ annually, which is the sum of inflation, $b$, and average productivity, $\pi$. Then, the nominal average wage for year $t, w_{t}$, is given by $w_{t}=w_{0} \mathrm{e}^{\lambda t}$, where $w_{0}$ is the average wage at time zero.

The covered labor force pays every year a proportional payroll tax, $p_{t}$, which is imposed on wage income only. Then, the total amount of payroll taxes collected in year $t$ is given by

$$
p_{t} w_{t} \beta_{t}\left(1-u_{t}\right) L_{t}
$$

The total amount of payroll taxes is distributed every year to the retired population. We distinguish here between two groups of the retired. The newly retired, $R_{1}$, receive a pension that is $\gamma_{t}$ percent of the nominal average wage for year $t$. The rest of the retired, $R_{t}-R_{1}$, have their pensions adjusted for inflation.

Then, the annual payroll tax rate for a price-indexed system is:

$$
p_{t}=\frac{\gamma_{t}}{\beta_{t}\left(1-u_{t}\right)}\left[\frac{R_{1}}{L_{t}}+\mathrm{e}^{-n t} \frac{R_{t}-R_{1}}{L_{t}}\right]
$$

For a wage-indexed PAYG system, the already retired, $R_{t}-R_{1}$, have their pensions adjusted for increases in the nominal average wage. Then, the payroll tax for a wageindexed system, $p_{t}^{w}$, is:

$$
p_{t}^{w}=\frac{\gamma_{t}}{\beta_{t}\left(1-u_{t}\right)} \frac{R_{t}}{L_{t}}
$$

So far we have analyzed annual payroll taxes. It is important to establish a range of the potential magnitude of the payroll taxes under a wide range of assumptions concerning various economic and demographic variables that affect the cost of such a pension system. For our purposes here, Equation (4) may be rewritten as follows:

$$
p=\frac{\gamma n}{(\delta+n) \beta(1-u)} \frac{\mathrm{e}^{-n t} \mathrm{e}^{-(\delta+n)}}{\mathrm{e}^{n m}-1}\left[1+(\delta+n)\left(\mathrm{e}^{n t}-1\right)\right]
$$

Taking the logarithmic derivative of function (6), we find that the growth rate of the payroll tax, $\dot{P}$, is related to the rates of change of the economic and demographic variables of the model as follows:

$$
\begin{aligned}
\dot{p}= & \dot{\gamma}-\dot{\beta}+\frac{1}{1-u_{t}} \frac{\mathrm{d} u}{\mathrm{~d} t} \\
& +\left[\frac{1}{n}-\frac{1}{\delta+n}-1-\frac{m \mathrm{e}^{n m}}{\mathrm{e}^{n m}-1}+\frac{\mathrm{e}^{\pi t}-1}{1+(\delta+n)\left(\mathrm{e}^{\pi t}-1\right)}\right] \frac{\mathrm{d} n}{\mathrm{~d} t} \\
& +\left[-\frac{1}{\delta+n}-1+\frac{\mathrm{e}^{\pi t}-1}{1+(\delta+n)\left(\mathrm{e}^{\pi t}-1\right)}\right] \frac{\mathrm{d} \delta}{\mathrm{d} t} \\
& +\left[\frac{(\delta+n) t \mathrm{e}^{\pi t}}{1+(\delta+n)\left(\mathrm{e}^{\pi t}-1\right)}-t\right] \frac{\mathrm{d} \pi}{\mathrm{d} t}-\frac{n \mathrm{e}^{n m}}{\mathrm{e}^{n m}-1} \frac{\mathrm{d} m}{\mathrm{~d} t}
\end{aligned}
$$


Equation (7) shows the relative importance of the factors that affect the growth rate of the payroll tax. A decomposition of the growth rate of the payroll tax is possible if information about the individual variables is available.

\section{Simulation of the pension system: 1980-2000}

In this section, we will employ Equation (4) to make a simulation of the Greek pension system for the period 1980-2000. Then we will decompose the growth rate of the payroll tax, in order to highlight those factors that played an important role in the formation of the cost of the program in the past.

Data for the simulation are derived from official sources. The data for active population (15-64), labor force, and retired population $(65+)$ are derived from the National Statistical Service of Greece (NSSG). The unemployment rates are derived from the Labor Force Surveys (NSSG), and the productivity growth rates are derived from the Eurostat.

We place special emphasis on the distinction between the "dependency ratio" and the "economic dependency ratio" (see Table 2). The former is the ratio of the retired $(65+)$ to the active population (15-64). But we use in our calculations the economic dependency ratio, $Z$, which is the ratio of the retired population $(65+)$ to the employed labor force. The ratio of the labor force to the active population determines the labor force participation rate, $\beta$, which is an important policy variable in our

Table 2 Selected data

\begin{tabular}{|c|c|c|c|c|}
\hline Year & $\begin{array}{l}\text { Dependency } \\
\text { ratio }\end{array}$ & $\begin{array}{c}\text { Economic dependency } \\
\text { ratio }\end{array}$ & $\begin{array}{l}\text { Replacement } \\
\text { rate }(\%)\end{array}$ & $\begin{array}{l}\text { Total pensions } \\
\text { as } \% \text { of } G D P\end{array}$ \\
\hline 1980 & 0.21 & 0.36 & 20 & 6.55 \\
\hline 1981 & 0.20 & 0.36 & 22 & 7.45 \\
\hline 1982 & 0.20 & 0.37 & 26 & 8.95 \\
\hline 1983 & 0.20 & 0.37 & 28 & 9.75 \\
\hline 1984 & 0.20 & 0.37 & 30 & 10.26 \\
\hline 1985 & 0.20 & 0.37 & 31 & 10.90 \\
\hline 1986 & 0.20 & 0.36 & 34 & 11.06 \\
\hline 1987 & 0.20 & 0.37 & 35 & 11.49 \\
\hline 1988 & 0.20 & 0.37 & 34 & 11.18 \\
\hline 1989 & 0.20 & 0.37 & 33 & 11.50 \\
\hline 1990 & 0.21 & 0.38 & 32 & 11.82 \\
\hline 1991 & 0.21 & 0.39 & 34 & 11.02 \\
\hline 1992 & 0.21 & 0.40 & 34 & 10.77 \\
\hline 1993 & 0.22 & 0.41 & 35 & 11.20 \\
\hline 1994 & 0.22 & 0.41 & 35 & 11.01 \\
\hline 1995 & 0.22 & 0.42 & 34 & 11.06 \\
\hline 1996 & 0.23 & 0.43 & 36 & 11.54 \\
\hline 1997 & 0.23 & 0.44 & 35 & 11.62 \\
\hline 1998 & 0.24 & 0.44 & 36 & 12.33 \\
\hline 1999 & 0.24 & 0.45 & 37 & 12.61 \\
\hline 2000 & 0.24 & 0.46 & 37 & 12.43 \\
\hline
\end{tabular}

Source: See definitions in text. 
model. Therefore, $Z=R /(\beta(1-u) L)$. In 2000 , the employment rate (labor force participation minus unemployment) was 55.9 percent in Greece, 63.7 percent in the EU, and 74.1 percent in the U.S.A. ${ }^{9}$ This is a crucial variable for pension systems because it is this portion of the labor force that actually pays social insurance contributions and supports the finances of the PAYG system. ${ }^{10}$

The replacement rate in our model is the ratio of total pension payments (derived from ESSPROS - European System of Social Protection Statistics) to the annual Wage Bill (derived from the Basic National Accounts ${ }^{11}$ ). These values are shown in Table 2. If Greece had a uniform pension system for the whole population, the replacement rates would represent a good proxy of the "adequacy" of the public pensions system. But as we mentioned in the second section above, the extensive segmentation of the current pension system renders calculation of the replacement rates for the whole system impossible. The values presented in Table 2 average-out the high pensions of employees in public companies with the (welfare) pensions of farmers. Yet, the replacement rate has increased from 20 percent in 1980 to 37 percent in 2000 .

The final column in Table 2 shows the total cost of public pensions as a percentage of GDP. This ratio has increased from 6.5 percent in 1980 to 12.5 percent in $2000 .^{12}$ Below we identify the main factors that have contributed to that increase.

Table 3 shows the required rates of social insurance contributions, $p$, under various scenarios. These contribution rates would apply if Greece had a uniform pension system for the whole population, and all employees were paying the same rate for the same earnings base. Scenario 1 is based on the actual values for the period 1980-2000. If in this period all employees were paying the same contribution rate on their earning, the required rate, $p_{1}$, to support the current level of benefits would range from 7 percent in 1980 to 16 percent in 2000 .

Scenario 2 shows the beneficial influence of increasing the labor force participation by 10 percentage points. If that had happened in Greece in the period 1980-2000, then the required tax rate, $p_{2}$, would be lower than $p_{1}$ by about 15 percent annually. Scenario 3 implies that the growth rate of productivity does not affect the annual cost of the pension system, because we have assumed that pensions are price indexed. Scenario 4 is a combination of scenarios 2 and 3 .

Two important conclusions are derived so far. The first is that if Greece had a uniform well-organized pension system for all employees and contributions and benefits were based on the same definition of earnings for all employees, then the current level of benefits in year 2000 would require a payroll tax of 16 percent. This compares with the nominal payroll tax for salaried employees, which is close to 30 percent (20 percent paid by employers/employees and 10 percent by the public budget). The second conclusion is that if labor force participation had been higher by 10 percentage points in the period 1980-2000, then the payroll tax would have been

\footnotetext{
${ }^{9}$ European Commission (2001a, b).

${ }^{10}$ McMorrow and Roeger (1999).

${ }^{11}$ Ministry of National Economy (2001, Table 8).

12 NSSG (2002).
} 
The Geneva Papers on Risk and Insurance - Issues and Practice

560

Table 3 Contribution rates: Percent of payroll

\begin{tabular}{ccccc}
\hline Year & $\begin{array}{c}\text { Scenario } 1 \\
p_{1}\end{array}$ & $\begin{array}{c}\text { Scenario } 2 \\
p_{2}\end{array}$ & $\begin{array}{c}\text { Scenario } \\
p_{3}\end{array}$ & $\begin{array}{c}\text { Scenario 4 } \\
p_{4}\end{array}$ \\
\hline 1980 & 7 & 6 & 7 & 6 \\
1981 & 9 & 7 & 8 & 7 \\
1982 & 10 & 8 & 10 & 8 \\
1983 & 11 & 9 & 10 & 9 \\
1984 & 11 & 9 & 11 & 9 \\
1985 & 11 & 10 & 11 & 10 \\
1986 & 12 & 10 & 12 & 10 \\
1987 & 13 & 11 & 13 & 10 \\
1988 & 12 & 10 & 12 & 10 \\
1989 & 12 & 10 & 12 & 10 \\
1990 & 12 & 10 & 12 & 12 \\
1991 & 13 & 11 & 12 & 13 \\
1992 & 14 & 12 & 14 & 12 \\
1993 & 15 & 13 & 15 & 12 \\
1994 & 14 & 12 & 14 & 12 \\
1995 & 14 & 12 & 15 & 14 \\
1996 & 15 & 13 & 15 & 14 \\
1997 & 15 & 13 & 16 & 14 \\
1998 & 16 & 14 & 16 & 16 \\
1999 & 16 & 14 & 16 & \\
2000 & 16 & 14 & & 14 \\
\hline
\end{tabular}

Scenario 1: Actual values for the period 1980-2000.

Scenario 2: Labor force participation: higher by 10 percentage points annually.

Scenario 3: Productivity growth: higher by 50 percent annually.

Scenario 4: Combination of scenarios 2 and 3.

lower by at least 15 percent annually. The lack of a uniform pension system as well as the fact that Greece has the lowest labor force participation rate in Europe indicates why Greece has the highest payroll tax rates in Europe.

Next, we may use formula (7) to decompose the growth rate of the payroll tax in the period 1980-2000. We assume a steady-state economy for this period in which the relevant economic/demographic variables assume the following values: the average annual compounded growth rate of the labor force, $n$, is 1 percent; the average growth rate of productivity, $\pi$, is 1 percent; the average unemployment rate, $u$, is 8 percent; the length of working life, $\mathrm{m}$, is 35 years; and the average mortality rate for the retired population is 10 percent. Then, the growth rate of the payroll tax, $\dot{p}$, is given by

$$
\begin{aligned}
\dot{p}= & \dot{\gamma}-\dot{\beta}+1.09 \frac{\mathrm{d} u}{\mathrm{~d} t}-28.6 \frac{\mathrm{d} n}{\mathrm{~d} t}-10.08 \frac{\mathrm{d} \delta}{\mathrm{d} t} \\
& -0.89 \frac{\mathrm{d} \pi}{\mathrm{d} t}-0.03 \frac{\mathrm{d} m}{\mathrm{~d} t}
\end{aligned}
$$

The average annual compounded growth of the payroll tax, $\dot{p}$, is 4.2 percent for the period 1980-2000. In Table 4 we decompose this annual change into its main factors. We estimate that during the period 1980-2000, the growth rate of the replacement rate (3.1 percent annually) contributed by 74 percent in the increase of the growth rate of 
Table 4 Decomposition of growth rate of payroll tax: 1980-2000

\begin{tabular}{lcc}
\hline Variable & Annual change & \% of variability \\
\hline$\dot{p}$ & $4.2 \%$ & - \\
$\dot{\gamma}$ & $3.1 \%$ & 73.8 \\
$\dot{\beta}$ & $0.0 \%$ & - \\
$u$ & $0.09(=1.09 \times 0.08)$ & -7.1 \\
$n$ & $-0.286(=-28.6 \times 0.01)$ & - \\
$\delta$ & - & -0.2 \\
$\pi$ & $-0.009(=0.89 \times 0.01)$ & -3.6 \\
$m$ & $-0.150(=5$ years $\times 0.03)$ & 26.2 \\
$\dot{z}$ & $1.1 \%$ & \\
\hline
\end{tabular}

the payroll tax. The labor force participation rate that remained stable all over the period did not affect the payroll tax at all. The very small increase in the covered labor force ( 1 percent annually) exercised a negative influence of 7 percent in the growth rate of the payroll tax. The cyclical variables of unemployment and productivity did not play any significant role. Finally, we estimate that an assumed increase of 5 years in the length of working life would have reduced the growth rate of the payroll tax by 15 bps annually.

We may note, also, that a simplified form of Equation (7) is given by

$$
\dot{p}=\dot{\gamma}-\dot{\beta}+\dot{z}
$$

In this case, we see (last row of Table 4) that a compounded annual growth rate of 1.1 percent in $z$ (increase from 0.36 in 1980 to 0.46 in 2000), has contributed by 26.2 percent to the growth rate of the payroll tax in the period 1980-2000.

\section{Projections of costs: 2005-2050}

In this section, we shall employ the model developed above to estimate the future costs of the Greek pension system. From the previous section we recall that $\dot{p}=\dot{\gamma}-\dot{\beta}+\dot{z}$. The replacement rate of the Greek pension system has reached a value of 37 percent in year 2000; we assume that in the future this rate will not exceed 40 percent. Therefore, the growth rate of the payroll tax in the period 2005-2050 will be determined by the growth rates of the labor force participation rate, $\dot{\beta}$, and the growth rate of the economic dependency ratio, $\dot{z}$.

In Table 5, we show the economic dependency ratios that will prevail under various assumptions concerning labor force participation rates. Data on the active and the retired population for the period 2005-2050 are derived from Tsimpos ${ }^{13}$ and NSSG. These projections have incorporated the 2001 census as well as the immigration flows that took place during the last decade. All ratios will have more than doubled between 2005 and 2050. Even with labor force participation rates of 80 percent, the economic

\footnotetext{
13 Tsimpos (2001).
} 
The Geneva Papers on Risk and Insurance - Issues and Practice

562

Table 5 Economic dependency ratios: 2005-2050

\begin{tabular}{lccccc}
\hline Year & Dependency ratio & \multicolumn{4}{c}{ Economic dependency ratios, when: } \\
\cline { 3 - 5 } & & $\beta=65 \%$ & $\beta=70 \%$ & $\beta=75 \%$ & $\beta=80 \%$ \\
\hline 2005 & 0.26 & 0.43 & 0.40 & 0.37 & 0.35 \\
2010 & 0.27 & 0.45 & 0.42 & 0.39 & 0.37 \\
2015 & 0.29 & 0.49 & 0.45 & 0.42 & 0.39 \\
2020 & 0.31 & 0.51 & 0.48 & 0.44 & 0.42 \\
2025 & 0.34 & 0.56 & 0.52 & 0.49 & 0.46 \\
2030 & 0.37 & 0.62 & 0.58 & 0.54 & 0.51 \\
2035 & 0.43 & 0.71 & 0.66 & 0.62 & 0.58 \\
2040 & 0.49 & 0.81 & 0.76 & 0.71 & 0.66 \\
2045 & 0.55 & 0.92 & 0.86 & 0.80 & 0.75 \\
2050 & 0.58 & 0.98 & 0.91 & 0.85 & 0.80 \\
\hline
\end{tabular}

Table 6 Costs of Greek pension system: 2005-2050. Scenario $1^{\mathrm{a}}$

\begin{tabular}{|c|c|c|c|c|}
\hline \multirow[t]{2}{*}{ Year } & \multicolumn{4}{|c|}{ Required payroll tax rates $(\%)$, when: } \\
\hline & $\beta=65 \%$ & $\beta=70 \%$ & $\beta=75 \%$ & $\beta=80 \%$ \\
\hline 2005 & 17.1 & 15.9 & 14.8 & 13.9 \\
\hline 2010 & 17.8 & 16.5 & 15.4 & 14.5 \\
\hline 2015 & 19.2 & 17.8 & 16.6 & 15.6 \\
\hline 2020 & 20.3 & 18.9 & 17.6 & 16.5 \\
\hline 2025 & 22.4 & 20.8 & 19.4 & 18.2 \\
\hline 2030 & 24.6 & 22.9 & 21.4 & 20.0 \\
\hline 2035 & 28.3 & 26.2 & 24.5 & 23.0 \\
\hline 2040 & 32.2 & 29.9 & 27.9 & 26.2 \\
\hline 2045 & 36.6 & 34.0 & 31.7 & 29.7 \\
\hline 2050 & 38.8 & 36.0 & 33.6 & 31.5 \\
\hline
\end{tabular}

assumptions: (1) Average productivity 1 percent annually for period 2005-2050; (2) Average unemployment rate 8 percent for period 2005-2050; (3) Values of $\beta$ increase from 65-80 percent; and (4) Replacement rate: 40 percent.

dependency ratios after 2025 will far exceed the current situation, reflecting the adverse demographic developments in the future.

Tables 6 and 7 present estimates of the future costs of the Greek pension system, on the basis of various scenarios concerning the increase in the economic dependency ratios, as well as the unemployment and productivity rates of the Greek economy in the period 2005-2050. The "worst" scenario is a projection of the economic conditions of the 1980s and the 1990s. If the Greek economy maintains its productivity and unemployment rates as well as the labor force participation rate at the corresponding rates of the period 1980-2000, then the required payroll taxes will have to increase from the current level of 17 percent to about 39 percent in 2050. This unsustainable level of insurance contributions may be restricted to about 30 percent by successive increases in the labor force participation rates (from 65 percent currently to 80 percent in 2050), doubling of the productivity and cutting the unemployment rate by two 
Table 7 Costs of the Greek pension system: 2005-2050. Scenario $2^{\mathrm{a}}$

\begin{tabular}{|c|c|c|c|c|}
\hline \multirow[t]{2}{*}{ Year } & \multicolumn{4}{|c|}{ Required payroll tax rates $(\%)$, when: } \\
\hline & $\beta=65 \%$ & $\beta=70 \%$ & $\beta=75 \%$ & $\beta=80 \%$ \\
\hline 2005 & 16.6 & 15.4 & 14.3 & 13.4 \\
\hline 2010 & 17.2 & 16.0 & 14.9 & 14.0 \\
\hline 2015 & 18.6 & 17.3 & 16.1 & 15.1 \\
\hline 2020 & 19.7 & 18.3 & 17.1 & 16.0 \\
\hline 2025 & 21.7 & 20.1 & 18.8 & 17.6 \\
\hline 2030 & 23.9 & 22.2 & 20.7 & 19.4 \\
\hline 2035 & 27.4 & 25.4 & 23.7 & 22.2 \\
\hline 2040 & 31.2 & 29.0 & 27.1 & 25.4 \\
\hline 2045 & 35.5 & 32.9 & 30.7 & 28.8 \\
\hline 2050 & 37.6 & 34.9 & 32.6 & 30.5 \\
\hline
\end{tabular}

aAssumptions: (1) Average productivity 2 percent annually for period 2005-2050; (2) Average unemployment rate 6 percent annually for the period 2005-2050; (3) Values of $\beta$ increase from 65-80 percent; and (4) Replacement rate: 40 percent.

percentage points. By comparing Tables 6 and 7, we realize that the improvement is almost exclusively due to the increase in the labor force participation rates between 2005 and 2050.

By using the formula $\dot{p}=\dot{\gamma}-\dot{\beta}+\dot{z}$, we may decompose the growth rate of the payroll tax rate for the period 2005-2050. The compounded annual growth rate for $p$ is 1.3 percent (increase from 17.1 percent in 2005 to 30.5 percent in 2050), for $\gamma$ is 0.0 percent (because we assume a constant replacement rate of 40 percent for all years), for $\beta$ is 0.46 percent (increase from 65 percent to 80 percent), and for $z$ is 1.4 percent (increase from 0.43 in 2005 to 0.80 in 2050). Therefore, the increase in the labor force participation rate will decrease the growth rate of the payroll tax rate by 35 percent, whereas the substantial increase in the economic dependency ratio will increase the growth rate of the payroll tax rate by 107 percent in the period 2005-2050. Similar results are reported in the EPC study. ${ }^{14}$

The analysis above shows that in case of no substantial reform, the public pension system will have its payroll tax rate more than double between now and 2050 . Obviously such a development would be economically infeasible because it would provoke severe adverse effects on employment, investment, and competition. In such a case, therefore, the public budget would have to shoulder most of the increased cost of financing pensions in the coming decades. This is not feasible either, because of the restrictions of the Fiscal Stability Pact. There is an urgent need, therefore, for an evaluation of the options for reform. In the next section, we use our analysis to make suggestions for the direction and timing of the necessary reforms. The key characteristic of the Greek pension system is its complexity and fragmentation. The analysis presented in this paper abstracts from much of the organizational complexity and yet shows that the macro-economic dilemmas faced by the country are stark and

\footnotetext{
${ }^{14}$ European Commission (2001a, b).
} 
extremely pressing. Allowing for the system's complexity by relaxing the simplifying assumptions made would reinforce the argument, by moving the analysis further in the same direction. For example, if one were to endogenize replacement rates, or to allow for the spread of auxiliary pensions and other maturation effects, this would lead to a further upward trend in average replacement rates. Allowing for greater complexity would, hence, deepen the expected disequilibria and would further increase the urgency of responding to them.

\section{Options for reform}

During the 1990s most of the European countries, even the new members of the European Union (EU) from eastern Europe, adopted pension reform schemes based on partially or fully funded systems. After long political deliberations, most countries have been able to reach a new trade-off between PAYG systems and funded pensions systems. $^{15}$

Greece has not been able so far to reach a consensus on pension reform, in order to face the demographic developments which shall prevail in the coming decades, despite the projected pension deficits that are expected to be the largest of any EU-15 country. ${ }^{16}$ Moreover, the current public pension system faces the serious problems of extensive segmentation and the lack of modern informational and organizational platforms. The previous analysis has shown that time is running out for a major reform, which will require the establishment and operation of a modern funded pension system alongside the existing PAYG system; this is an inescapable necessity for Greece, as it has been proven to be for all industrial countries.

It is suggested that there are three major strategic dimensions of a pension reform, all of which must start simultaneously: (a) improvement of the economic dependency ratios, (b) reengineering of the PAYG system, and (c) establishment of a modern funded pension system.

As far as the first factor is concerned, our analysis has shown that the economic dependency ratios may be increased in two ways: (a) by increasing the labor force participation rates and/or (b) by increasing retirement age. The latter requires a political decision, whereas the former represents a major issue of economic growth policy. From Tables 5 and 6, we may discern that in order to keep the cost of the pension system at the current level (payroll tax 17.1 percent in 2005), the labor force participation rate has to increase from 65 percent in 2005 to 70 percent in 2010 , to 75 percent in 2020, and to 80 percent in 2025. This is necessary in order to secure a "transition period" for the phase-in of the new funded pension system. However, the attainment of this goal requires major growth initiatives in the economy and the introduction of substantial "flexibility" measures in the labor market. Otherwise, retirement ages will have to be increased gradually in the coming decades, or the significant immigration inflows of the 1990s (about 10 percent of the population) will have to be repeated.

\footnotetext{
${ }^{15}$ Börsch-Supan et al. (1999).

${ }^{16}$ Government of Greece (2001a, b); and European Commission (2001a, b).
} 
Table 8 Projected costs of new pension system (Drs. Trillion/current prices) (Effective retirement age: 65 years)

\begin{tabular}{lcccc}
\hline Year & $\begin{array}{c}\text { Reduced } \\
\text { PAYG costs }\end{array}$ & $\begin{array}{c}\text { Costs of fully } \\
\text { funded pensions }\end{array}$ & $\begin{array}{c}\text { Total cost of } \\
\text { new system }\end{array}$ & $\begin{array}{c}\text { Cost of current } \\
\text { system }\end{array}$ \\
\hline 2000 & 4.4 & 1.2 & 5.6 & 4.4 \\
2010 & 4.2 & 1.2 & 5.4 & 5.2 \\
2020 & 4.1 & 1.2 & 5.3 & 6.1 \\
2030 & 3.0 & 1.2 & 4.2 & 7.1 \\
2040 & 3.0 & 1.1 & 4.1 & 7.6 \\
2050 & 3.0 & 1.1 & 4.1 & 7.6 \\
\hline
\end{tabular}

Source: Nektarios (2000).

Second, the reengineering of the current segmented PAYG pension system should commence immediately. The goals should be (a) to secure the intergenerational as well as the intragenerational equity and fairness of the system, (b) to improve administration, and (c) to reduce contribution evasion. Such goals may be attained with the establishment of a uniform PAYG system that will merge all existing primary pension funds. Our analysis in this paper has shown that if that had happened in the past, the overall payroll tax rate would have been much lower than the current one.

Third, the major part of the reform will necessitate the establishment of a fully funded pensions system, which will gradually (up to 2025) replace half of the protection offered by the PAYG system. Participation would be compulsory, with complete portability of pension rights among the pension funds. Financing should be based on a redirection of a portion of the current payroll tax, because it is not feasible to increase further the payroll tax. ${ }^{17}$ The main problem with the introduction of a funded pension system is the increased cost during the transition period, when the current generation has to bear both the cost of the PAYG system as well as the cost of financing the new system. There is an extensive literature with proposed solutions to this problem. ${ }^{18}$

Nektarios ${ }^{19}$ has shown that the earlier a funded pension system is adopted, the better it is for the public finances of Greece. The last column of Table 8 shows that in case of no reform, the costs of the current pension system will almost double after 2025, threatening the public finances of the country. These results are confirmed by the findings of this paper. On the other hand, if a funded pension system had been adopted in 2000, along the lines suggested above, then the cost of the New System (scaled down PAYG system and a new funded pension system, with an aggregate replacement rate of 70 percent) would be reduced dramatically after the year 2025 . The suggested pension system would guarantee the protection of the population in the long

\footnotetext{
${ }^{17}$ Nektarios (1996); Börsch-Supan and Tinios (2001).

${ }^{18}$ Kotlikoff (1995, 1996); Feldstein (1996a, b and 1998); Feldstein and Samwick (1998); Neumann (1997); Miles and Timmermann (1999); Börsch-Supan (2000).

19 Nektarios (2000).
} 
run and at the same time would offset most of the future adverse demographic developments.

\section{Conclusions}

The Greek pension system is a typical example of the Mediterranean welfare model, with extensive segmentation, very high payroll tax rates, and inadequate benefits for the majority of the recipients. We show in this paper that this paradox is resolved if we take into consideration the labor force participation rate. For the Greek economy, this rate is the lowest in the EU (15 members) and has remained so for almost two decades. The direct result of this fact is that the economic dependency ratio is very high, and this implies that the relatively restricted basis of the employed labor force has to bear the cost of financing the pensions of the total number of current pensioners.

Our analysis has shown that if, on top of the existing problems, we add the adverse demographic developments that are going to prevail in the coming decades, then the current PAYG pension system will incur deficits of such amounts that will threaten the public finances of the Greek state.

For reform purposes, the low labor force participation rate may provide a "window of opportunity", however. That is, by increasing flexibility in the labor market the size of the employed labor force will increase, providing financial relief to the current PAYG pension system. The benefits of such policies will be exhausted before 2025, however. In the meantime, the last opportunity should be exploited for developing a modern funded pension system that will gradually substitute for roughly half of the pension benefits provided by the PAYG system. This way the adverse demographic developments will be offset substantially, and the long-run financial burden on the state budget will be kept in a feasible range. The reform process should be completed with a total overhaul of the current PAYG system, in the direction of establishing a single and uniform pension system for the whole population.

\section{References}

Börsch-Supan, A. (2000) 'A model under siege: A case study of the German retirement insurance system', The Economic Journal 110: F24-F45.

Börsch-Supan, A., Palacios, R. and Tumbarello, P. (1999) Pension Systems in the Middle East and North Africa: A Window of Opportunity, Washington: The World Bank.

Börsch-Supan, A. and Tinios, P. (2001) 'The Greek pension system', in R. Bryant, N. Garganas and G. Tavlas (eds) Greece's Economic Performance and Prospects, Athens: Bank of Greece, pp. 435-533.

Center for Economic Planning and Research (1976) Social Insurance: Development Program: 1976-1980, Athens: Center for Economic Planning and Research.

Commission for the Long-run Economic Policy (1997) Economy and Pensions, Athens: Commission for the Long-run Economic Policy.

European Commission (2001a) Employment in Europe, Brussels: European Commission.

European Commission (2001b) Budgetary challenges posed by ageing populations, EPC/PCFIN/655/01-EN Final, Brussels.

Eurostat (2003 and various issues) European System of Social Protection Statistics, Brussels: Eurostat.

Feldstein, M. (1996a) 'The missing piece in policy analysis: Social security reform', American Economic Review 86(May): 1-14. 
Feldstein, M. (1996b) Would privatizing social security raise economic welfare?, NBER Working paper 5281, Washington.

Feldstein, M. (1998) Social security pension reform in China, NBER Working paper 6794, Washington.

Feldstein, M. and Samwick, A. (1998) 'The transition path in privatizing social security', in M. Feldstein (ed) Privatizing Social Security, Chicago: University of Chicago Press.

Ferrera, M. (1996) 'The southern model of welfare in social Europe', Journal of European Social Policy 6(1): 17-37.

Government of Greece (2001a) Review of the Retirement Pension System: Report by the Government's Actuary's Department, United Kingdom, Athens: Government of Greece.

Government of Greece (2001b) Review of the Retirement Pension System: Financial Estimates - G.A.D. United Kingdom, Athens: Government of Greece.

IMF (2006) Greece: Selected Issues, Washington, DC: IMF Country Report No. 06/5.

Kotlikoff, L. (1995) Privatization of social security; How it works and why it matters, NBER Working paper 5330 .

Kotlikoff, L. (1996) 'Privatizing social security at home and abroad', American Economic Review 86: 368-372.

McMorrow, K. and Roeger, W. (1999) The Economic Consequences of Ageing Populations, Brussels: European Commission.

Miles, D. and Timmermann, A. (1999) 'Risk sharing and transition costs in the reform of pension systems in Europe', Economic Policy 14: 251-286.

Ministry of National Economy (2001) Basic National Accounts, Athens: Ministry of National Economy.

Ministry of Social Services (1981) Social Insurance in Greece, Athens: Ministry of Social Services.

Mylonas, P. and de la Maisonneuve, C. (1999) The problems and prospects faced by PAYG pensio systems: A case study of Greece, OECD Economic Department, Working paper 215, Paris.

National Statistical Service of Greece (NSSG) (2002 and various issues) Social Protection in Greece: Expenditures and Revenues, Athens: National Statistical Service of Greece (NSSG).

Nektarios, M. (1996) Social Insurance in Greece, Athens: Forum.

Nektarios, M. (2000) 'Financing public pensions in Greece', Spoudai 50(3-4): 125-139.

Neumann, M. (1997) Replacing Germany's Public Old-Age System with a Fully-Funced System, Working paper, Frankfurter Institute.

OECD (1997) Annual Review-Greece, Paris: OECD.

Provopoulos, G. (1987) Social Insurance, Athens: 1I0BE.

Roseveare, D.W., Leibfritz, W., Fore, D. and Wurzel, E. (1996) Ageing populations, pension systems and government budgets: Simulations for 20 OECD countries, OECD Economic Department Working paper 168.

Tatsos, N. (2001) Underground Economy and Tax Evasion in Greece, Athens: Papazisis (in Greek).

Tsimpos, K. (2001) 'The importance of immigration in the estimation of the size of population of Greece', in E. Kikilias (ed) Demographic Ageing, Labour Market and the Social Protection System, Athens: National Institute of Labour and Sakkoulas Editions.

\section{Appendix}

\section{A demographic model}

In this appendix, we state more explicitly the demographic background of the model used in the main text.

The population we have in mind was $L_{0}$ in time zero (for convenience $L_{0}$ may be set equal to 1 in calculations). We are interested in the composition of this population after $t$ years. Our main concern is with the portion of the total population that is in the labor force, and also the portion that is in retirement. The growth rate of the population is $n$ annually, and the birth rate is $d$ annually.

As far as the working population is concerned, people enter the labor force at the age of 16 and retire upon attainment of age 65 . 
Generally, group of workers of age $(16+k)$ is given by $d L_{0} \mathrm{e}^{n(t-k)}$ or $d L \mathrm{e}^{n(t-64)} \mathrm{e}^{n(64-k)}, \forall k=0,1,2, \ldots 48$.

The total labor force at year $t, L_{t}$, may be obtained by summing up the members of each age group for all ages between 16 and 65 .

We have:

$$
\begin{aligned}
L_{t} & =d L_{0} \mathrm{e}^{n(t-16)}+d L_{0} \mathrm{e}^{n(t-17)}+\cdots+d L_{0} \mathrm{e}^{n(t-64)} \\
& =d L_{0} \mathrm{e}^{n(t-64)}\left(\mathrm{e}^{48 n}+\mathrm{e}^{47 n}+\cdots+\mathrm{e}^{n}+1\right) \\
& =d L_{0} \mathrm{e}^{n(t-64)} \int_{0}^{48} \mathrm{e}^{n t} d t
\end{aligned}
$$

or

$$
L_{t}=d L_{0} \frac{1}{n} \mathrm{e}^{n(t-64)}\left(\mathrm{e}^{48 n}-1\right)
$$

The ratio of the age group $(16+k), k=0,1,2, \ldots 48$, to the total labor force, $L_{t}$, denoted by $f_{k}$, is given by

$$
f_{k}=\frac{d L_{0} n \mathrm{e}^{n(t-64)} \mathrm{e}^{n(64-k)}}{d L_{0} \mathrm{e}^{n(t-64)}\left(\mathrm{e}^{48 n}-1\right)} \Rightarrow f_{k}=\frac{n \mathrm{e}^{n(64-k)}}{\mathrm{e}^{48 n}-1}
$$

and therefore:

$$
f_{(16+k)}=\frac{n \mathrm{e}^{n(48-k)}}{\mathrm{e}^{48 n}-1} \quad \forall k=0,1,2, \ldots, 48
$$

As far as the retired population is concerned, we assume that retirement life starts at the beginning of the year in which workers reach at 65. Retired people die at the rate $\delta$ percent annually and deaths are concentrated at the beginning of the year.

Generally,

$$
\text { group of retired of age }(65+m): d L_{0} \mathrm{e}^{-(\mu+1) \delta} \mathrm{e}^{n(t-65-\mu)}
$$

or

$$
d L_{0} \mathrm{e}^{-(\mu+1) \delta} \mathrm{e}^{n(t-64)} \mathrm{e}^{-n \mu} \quad \forall \mu=0,1,2, \ldots \infty .
$$

We may obtain the total retired population at year $t, R_{t}$, by summing up the members of each age group for all ages between 65 and $+\infty$.

We have:

$$
\begin{aligned}
R_{t} & =d L_{0}\left(\mathrm{e}^{-\delta} \mathrm{e}^{n(t-65)}+\mathrm{e}^{-2 \delta} \mathrm{e}^{n(t-66)}+\cdots\right) \\
& =d L_{0} \mathrm{e}^{-\delta} \mathrm{e}^{n(t-65)}\left(1+\mathrm{e}^{-\delta} \mathrm{e}^{-n}+\mathrm{e}^{-2 \delta} \mathrm{e}^{-2 n}+\cdots\right) \\
& =d L_{0} \mathrm{e}^{-\delta} \mathrm{e}^{n(t-65)} \int_{o}^{+\infty} \mathrm{e}^{-(\delta+n) t} \mathrm{~d} t \\
& =d L_{0} \mathrm{e}^{-\delta} \mathrm{e}^{n(t-65)} \frac{-1}{\delta+n}(-1)
\end{aligned}
$$

because: if $\lambda<0$, then $\mathrm{e}^{\lambda t} \rightarrow 0$ as $t \rightarrow+\infty$. 
Hence:

$$
R_{t}=d L_{0} \frac{1}{\delta+n} \mathrm{e}^{-\delta} \mathrm{e}^{n(t-65)}
$$

Finally, the ratio of the age group $(65+n)$ to the total retired population, denoted by $g_{\mu}, \mu=0,1,2, \ldots+\infty$, is given by

$$
g_{(65+\mu)}=\frac{d L_{0} \mathrm{e}^{-(\mu+1) \delta} \mathrm{e}^{n(t-65)} \mathrm{e}^{-n m}}{d L_{0} \frac{1}{\delta+n} \mathrm{e}^{-\delta} \mathrm{e}^{n(t-65)}}
$$

or

$$
g_{(65+\mu)}=(\delta+n) \mathrm{e}^{-\mu(\delta+n)} \quad \forall \mu=0,1,2, \ldots+\infty
$$

\section{About the Author}

Milton Nektarios is associate professor of insurance at the Department of Statistics and Insurance, University of Piraeus, Greece. He holds a Ph.D. from Temple University. His main research interests are in pension systems, health insurance, catastrophe risks management, and efficiency and productivity in the Greek insurance market. He is the author of the book Public Pensions, Capital Formation, and Economic Growth (Boulder Colorado: Westview Press, 1982). During the period 1999-2004, he served as Governor of the Social Insurance Organisation of Greece. 